\title{
Institutional Mechanisms for the Rights and Protection of the Child in Albania, Their Practical Operation
}

\author{
Alma Tandili (Lleshi) \\ University of Tirana, Albania, Faculty of Social Sciences, \\ Department of Policy and Social Work, Msc
}

\begin{abstract}
For the functioning of the integrated child protection system, it is necessary to establish structures and make them operational responsible for policy making and their implementation on the issues affecting the rights and protection of the child. Receiving the recommendation to open accession negotiations for Albania's membership in the European Union places the institutions responsible for the approximation of legislation with responsibility. The new legal framework for the rights and protection of the child is designed in the spirit of the European Union by creating institutional mechanisms. This article will describe the functionality of these mechanisms in practice by highlighting field problems and concrete data on cases of children in need of protect.
\end{abstract}

Keywords: institutional mechanisms, rights of the child, children in need

\section{Introduction}

In the last 3 years, Albania has made significant changes in the field of children's rights and protection. These legal changes have brought about a reorganization of the child protection system but also specific obligations for institutions, organizations or even natural persons. These changes and legal responsibilities have the ultimate purpose: the protection of the child.

Law 18/2017 "On the Rights and Protection of the Child" with the bylaws in its implementation, require to regulate all mechanisms of functioning of children's rights, case management procedures, cooperation between state bodies and organizations, imposing sanctions in the event of failure to comply with the prescribed procedures and other aspects of the rights and protection of the child.

This article aims to outline the institutional mechanisms of child protection in Albania and the findings in their implementation in practice. Albanian legislation on the rights and protection of child provides for effective mechanisms and the functioning of institutions charged with taking concrete measures to promote, respect and protect the rights of the child, as well as to establish an integrated and functional child protection system, for the prevention and effective response to all forms of violence, abuse, exploitation and neglect.

Referring to Law 18/2017 "On the Rights and Protection of the Child", "Integrated Protection System" is the set of legal, policy and necessary services in all areas, especially those of social welfare, education, health, security and justice, in order to prevent and respond to the risks 
that arise during their implementation. A genuine child protection system seeks to include mechanisms that are responsible for protecting the child and responding to the best interests of the child. This system includes well-defined measures and procedures for decision-making on the rights and protection of the child.

For the purpose of writing this scientific article, a qualitative research method was used in conducting interviews with professionals who are part of the institutional advisory and coordination mechanisms. Other instruments obtained in the writing of the article are reviews of local and foreign literature.

\section{Institutional mechanisms in the Republic of Albania:}

In Albania, the institutional advisory and coordination mechanisms for the rights and protection of the child, in accordance with the scope of their activity, are at central and local level. These mechanisms collaborate and coordinate their work in implementing state legislation and policies on child rights and protection, as well as collaborating with non-profit organizations to implement national and local policies for the protection of child rights and the provision of services which are necessary for their protection.

\section{Institutional advisory and coordination mechanisms}

The National Council for the Rights and Protection of the Child at central level;

Since 2017, which coincides with the entry into force of the law, the National Council for the Rights and Protection of the Child is summoned periodically and functions according to the Decision of the Council of Ministers which regulates the procedures of its chairmanship and meetings. A novelty of this council is the participation of children in roundtables with important institutional and nongovernmental organizations stakeholders. Giving voice to children nationally is an achievement in respecting and enforcing the rights of children in Albania.

Inter-sectorial technical group at municipal level or administrative unit at local level.

The inter-sectorial technical group at the municipal or administrative level is one of the formats that the law requires to be set up to manage cases of children in need of protection. In Albania, the inter-sectorial technical group is at the municipal or administrative level and is regulated by a decision of the Council of Ministers. According to the assessment made in 61 municipalities of the country, in 8 municipalities during 2019 the inter-sectorial technical group has never been summoned and no case of children in need of protection has been managed. 53 municipalities have set up inter-sectorial technical groups according to case typologies in the management process.

\section{Structures for the rights and protection of the child in central level}

Minister coordinating the work on issues for the rights and protection of the child;

In 2017 the Albanian government was restructured and the responsible minister who coordinates work on issues on the rights and protection of child is the Ministry of Health and Social Protection.

State Agency for the Rights and Protection of the Child;

The State Agency for the Rights and Protection of the Child is a legal entity under the ministry that coordinates work on child rights and protection issues - as of 2017 it is under the Ministry 
of Health and Social Protection. The Agency is headed and represented by the chairperson and the structure of the agency are approved by the Prime Minister, on the proposal of the Minister coordinating the work on child rights and protection issues. At the moment, the structure is composed of 1 chairperson and 6 employees of civil servant status. Given the legal duties entrusted to this institution, this structure is small in human resources.

Each responsible minister, according to the field they cover, regarding the rights and protection of the child.

In the implementation of laws and by-laws in the function of enforcing the rights and protection of the child, it is impossible to cover only one state structure. The functioning of the entire integrated child protection system requires legislative and law enforcement structures to be engaged. Ministry of Finance and Economy, Ministry of Interior, Ministry of Europe and Foreign Affairs, Ministry of Education, Sport and Youth, Ministry of Justice, Ministry of Culture, Ministry of Health and Social Protection - are the main ministries which are part of the National Council on the Rights and Protection of the Child and are charged with the Decision of the Council of Ministers, National Strategic Plans with tasks in the implementation of children's rights.

\section{Structures for the protection of the child in local level}

Municipality; The structure responsible for social services in the municipality; Child Protection Unit within the structure responsible for municipal social services; Needs assessment and referral unit to municipality or administrative units; Child Protection Officer at Child Protection Unit and Needs Assessment and Referral Unit.

The new territorial division divides Albania into two levels of local government units, in 12 counties which are further subdivided into 61 municipalities. Law 18/2017 "On the Rights and Protection of the Child" imposes on municipalities to establish at the municipal level and at the level of the administrative unit, depending on the respective structures for the protection of the child, in accordance with the standards and, through them, of an integrated child protection system.

Based on field interviews with local staff and their assessment, the municipality appears to be the weakest level in ensuring children's rights, although legally it holds the most weight. The structures responsible for social services in municipalities have not yet been established in 61 municipalities. Only $4 \%$ of the municipalities have consolidated the structure responsible for social services in the municipalities.

Law 10/2017 establishes a legal criterion where for each administrative unit and at least 3000 children a child protection officer is to be assigned. Referring to the data of the State Agency for the Rights and Protection of he Child, there are 235 administrative units in which 5 of them are not covered by Child Protection Officers.

An important element is that of the 230 employees assigned as CPO, 171 of them perform other functions (economic aid worker, domestic violence coordinator).

In the organization of human resources for the establishment of a needs assessment and referral unit at the municipalities or administrative units, there is only one case registered in one of the administrative units of the Tirana municipality - a structure which is still in the pilot phase. 
Legislation imposes numerous duties and responsibilities on the Child Protection Officer but the main function of this structure is to manage cases of children in need of protection.

Based on the field assessment, for 2019, child protection officers in 61 municipalities of the Republic of Albania have managed a total of 2449 cases of children in need of protection. In 61 CPUs - 8 of them have not managed a case. The cases are of different typologies physical violence, sexual violence, psychological violence, trafficking, children in street situation, neglect, socioeconomic problem, disability, children in conflict with the law, etc.

The application of protective measures, as a legal instrument to remove the child from danger and manage it continuously, is one of the most important processes that require the engagement of institutional mechanisms acting on the highest interest of the child.

For 2019, 100 emergency protection measures, 31 alternative care arrangements and 90 specialized child surveillance measures have been applied.

Operation of this chain requires $24 / 24$ and $7 / 7$ engagement of all structures.

\section{Conclusion}

Albania has made significant progress in the area of the rights and protection of child in drafting legislation but still has many difficulties in implementing it in practice.

Law 18/2017 "On the Rights and Protection of the Child" provides for institutional mechanisms for the rights and protection of the child. These mechanisms are in place but there is a shortage of human resources and funding to make them fully operational.

At the local level there are still shortcomings in the establishment of structures responsible for social services in the municipality, the completion of the legal ceiling for the placement of a child protection officer in administrative units with more than 3,000 children, and the staffing of assessment units for child needs and referral units to the municipality or administrative units. In the 61 municipalities of the Republic of Albania, 230 employees assigned as CPOs, 171 of them perform other functions - worsening the work and affecting the quality of case management in need of protection.

Law 18/2017 provides for the establishment of a inter-sectorial technical group at the local level for the management of cases of children in need of protection. There is no consolidation of this group in 61 municipalities of the country - 8 municipalities report 0 cases managed for 2019.

\section{References}

[1] Law 18/2017 "On the rights and protection of the child",

[2] Law 115/2014 "On the administrative-territorial division of local government units in the Republic of Albania"

[3] Decision of Council of Ministers no. 54, dated 31.01.2018 "On the Rules of Procedure of the National Council for Rights and Protection";

[4] Decision of the Council of Ministers Nr. 91, dt. 14.02.2018 "On the Procedures for Performing Control and Imposing Sanctions by the State Agency for the Rights and Protection of the Child";

[5] Decision of the Council of Ministers No. 148, dated 13.03.2018 "On the Determination of the Rules of Cooperation between the Institutional Advisory and Coordination Mechanisms, the Structures for the Rights and Protection of the Child 
and the Non-profit Organizations, for the Implementation of National and Local Policies and for Necessary Child Protection Services".

[6] Decision of Council of Ministers no. 353, dt. 12.06.2018 "On the rules of operation of the inter-sectorial technical group on child protection at municipalities and administrative units"

[7] Decision of the Council of Ministers no. 578, dated 3.10.2018 "On referral and case management procedures, drafting and content of the individual protection plan, financing the costs for its implementation, as well as implementation of protection measures".

[8] Decision of the Council of Ministers Nr. 565, dated 29.9.2018 "On the coordination of activity between institutional advisory and coordination mechanisms and structures at central and local level on issues related to the rights and protection of the child"

[9] Decision of the Council of Ministers Nr. 636, dated 26.10.2018 "On the determination of the types, manner of exchange and processing of information and statistical data required by the State Agency for the Rights and Protection of the Child at the responsible state structures at central and local level".

[10] Decision of the Council of Ministers Nr. 635, dated 26.10.2018 "On the activity of child protection structures, in relation to a child under the age of criminal responsibility, suspected or having committed a criminal offense".

[11] Decision of Council of Ministers No.129, dated 13.03.2019 "Procedures for the Identification, Immediate Assistance and Referral of Economically Used Children, Including Children in Street Situation"

[12] Decision of the Council of Ministers No.111, dated 06.03.2019 "On the Procedures and Rules for the Return and Repatriation of the Unaccompanied Child"

[13] Decision of the Council of Ministers No.186, dated 04.04.2019 "On the criteria for the employment of the employees of the structures for child protection and of the employees working with children"

[14] Instruction No.556, dated 556, dated 29.07.2019 "On the manner of placement in the Institutions of Social Care for the child against whom protection measure is taken";

[15] Instruction No.584, dated 31.7.2019 “On the concrete rules, procedures, and actions of the central or local government authorities, as well as the obligations of medical personnel or professionals in other fields related to the prevention or treatment of cases child abandonment in health care institutions";

[16] Instruction No. 659, dated 23.09.2019 "On the rules and procedures for covering the expenses in the provision of educational, health or rehabilitation services, in accordance with the specific needs, in a local government unit other than the child with disabilities lives" (Joint Instruction Article 32, point 4, with MASR)

[17] instruction No. 650, dated 13.09.2019 "On the Establishment of Criteria and Procedures for the Selection of Procedural Representatives for Children in Conflict with the Law, Child Victims and Witnesses in Criminal Proceedings" (Joint Instruction Article 49, paragraph 4, with MoJ)

[18] Instruction No. 651, dated 13.09.2019 “On the procedures of reporting cases of children in need of protection" (Joint Instruction Article 67, point 7, with MASR and MoI)

[19] Guidelines on assessing and determining the best interests of the child 2018 Provisional Release 
[20] https://cms.emergency.unhcr.org/documents/11982/43375/UNHCR\%2C+Guideli nes+on+Assessing+and+Determining+the+Best+Interests+of+the+Child\%2C+2018/ e7c38334-3bc0-41d2-af39-3b4c998def67

[21] http://shendetesia.gov.al/

[22] www.femijet.gov.al

[23] Clancy, T., Stiner, C., \& Koltz, T. (2002). Shadow warriors: Inside the special forces. New York, NY: Putnam

[24] Austin, J. H. (1998). Zen and the brain: Toward an understanding of meditation and consciousness. Cambridge, MA: MIT Press.

[25] Calarco, M., \& Atterton, P. (2009). Animal philosophy: Essential readings in continental thought. New York, NY: Continuum.

[26] Chen, J. Q. (2003). Intelligence: Multiple intelligences. In J. Guthrie (Ed.),Encyclopedia of education (pp. 1198-1201). New York, NY: Macmillan. 